\title{
DOI: 10.7596/taksad.v6i3.938
}

Citation: Yalap, H. (2017). Yeni Bir İhtilâcnâme - Seğirnâme Nüshas1. Journal of History Culture and Art Research, 6(3), 682-695. doi:http://dx.doi.org/10.7596/taksad.v6i3.938

\section{Yeni Bir İhtilâcnâme / Seğirnâme Nüshası}

\section{A New ihtilâcnâme / Seğirnâme Manuscript}

\section{Hakan Yalap ${ }^{1}$}

\begin{abstract}
For mankind, the feeling of knowing beyond the moment has always been a matter of curiosity. For this reason, it can be seen that fortune and kinds of fortune are constant and influential in all cultures. Therefore, in literature, literary forms are found around the concept of "fortune". The fortune book Irk Bitig written in Gokturk letters is the earliest known document of this type.
\end{abstract}

Twitching is an uncontrollable movement which may occur somewhat part of the body, that is the muscles beneath the skin move slightly with the skin. The works taken on the basis of the interpretations made on the basis of twitching any of the organs of the human body are called seğirnâme or ihtilâcnâme. Seğirnâme's, which were dated to ancient times in Turkish culture and Turkish literature, have an important place for the history of literature and language. There have been many studies on these types of manuscripts in Turkey and in the world's libraries. When the studies are examined, it has been seen that the texts of seğirrnâme texts are mostly prose texts, but there are also verse texts. In this work, which is based on a selfcontained manuscript in the Library of the University of Leipzig, the work on public works was evaluated and the text was transcribed into the transcription alphabet and the language and spelling characteristics were examined. The text in which 138 twitches are involved can be considered voluminous. As a result of the new academic studies from seğirnâme manuscripts to be carried out after that, a more detailed informations about the type of seğirnâme's, the contents of the languages and language features will be reached.

Keywords: Classical Turkish Literature, Fortune, Twitching, Seğirnâme, İhtilâcnâme.

\footnotetext{
1 Nevşehir Hacı Bektaş Veli Üniversitesi Eğitim Fakültesi Türkçe Eğitimi A. B. D. E-mail: hakanyalap@ hotmail.com
} 


\section{Öz}

İnsanoğlu için bulunduğu anın ötesini bilme ve ötesinde yaşama hissi her dönem etkili olmuştur. $\mathrm{Bu}$ sebeple tüm kültürlerde fal ve fal türlerine ilginin sürekli ve etkili olduğu görülebilir. Dolayısıyla edebiyatta "fal" kavramı etrafında şekillenmiş edebî türlere rastlanmaktadır. Göktürk harfleri ile yazılmış olan Irk Bitig adlı fal kitabı bu türün şimdilik bilinen en eski belgesidir.

Seğirmek, vücudun bir yerinde deri ile birlikte derinin hemen altındaki kasların hafifçe oynamasıdır. İnsan bedeninin herhangi bir organının seğirmesine dayanılarak yapılan yorumlar neticesinde kaleme alınan eserlere seğirnâme veya ihtilâcnâme adı verilir. Türk kültüründe ve Türk edebiyatında çok eski dönemlere tarihlenen seğirnâmeler edebiyat ve dil tarihi için önemli bir yere sahiptir. Türkiye ve dünya kütüphanelerinde pek çok yazma nüshası olan bu türler hakkında çalışmalar yapılmıştır. Yapılan çalışmalar incelendiğinde seğirnâme metinlerinin çoğunlukla mensur metinler olduğu, ancak manzum seğirnâmelerin de bulunduğu görülmüştür. Leibzig Üniversitesi Kütüphanesindeki müstakil bir yazma nüshaya dayanan bu çalışmada umumi olarak seğirnâmeler üzerine yapılan yayınlar değerlendirilerek metin transkribe edilmiş, dil ve imlâ özellikleri incelenmeye çalışılmıştır. 138 seğirmenin yer aldığı metin, bu hâliyle hacimli sayılabilir. Yeni seğirnâme nüshaları üzerinden bundan sonra yapılacak akademik çalışmalar neticesinde seğirnâme türü, seğirnâmelerin içeriği ve dil özellikleri hakkında daha etraflı bilgilere ulaşılacaktır.

Anahtar Kelimeler: Klâsik Türk Edebiyatı, Fal, Seğirme, Seğirnâme, İhtilâcnâme.

\section{Giriș:}

Edebî metinlerin her nev'i içinden çıktığı cemiyetin temel taşlarını oluşturmakta ve sonu gelmez bir bulmaca olan millî şifreler bu metinler vasıtasıyla çözülebilmektedir. Böylelikle toplumun en ince damarlarına nüfuz edilebilmektedir.

İnsanoğlu için bulunduğu anın bir adım ötesinde yaşamak önemli bir ruh hâli olarak tüm zamanlarda ve tüm kültürlerde dikkat çekicidir. Bu bir adım öte durumu doğal olarak geleceği merak hissinin bir sonucudur. İşte bu gelecekten haberdar olma hâli "fal” kavramı etrafında şekillenmiş ve doğal olarak edebiyatta da yer bulmuştur. Türkler için "nitekim IX. yüzyıldan kalan ve Göktürk harfleri ile yazılmış olan Irk Bitig adlı fal kitabı bu ilginin yazılı bir belgesi durumundadir" (Ersoylu, 1985:27).

Ersoylu (1985), insanın geleceğine ait yorumların en önemlilerinden birinin kişinin kendi bedeni ile ilgili olanı olduğunu belirtir. Bir kimsenin vücudundaki herhangi bir uzuv seğirdiği zaman bu durumun kişinin gelecekteki durumuna, işine vb. hususlarına ait tahminler yapılmaktadır. İşte insan bedeninin herhangi bir organının seğirmesine dayanılarak yapılan 
yorum işine ilm-i ihtilâc adı verilmektedir. Bir fal çeşidi olan vücut organlarının kımıldaması üzerine yapılan yorumlar neticesinde manzum veya mensur pek çok eser kaleme alınmıştır ki bunlar edebiyat tarihimizde seğirnâme veya ihtilâcnâme adıyla anılır.

Seğirmek kelimesi, Türkçe Sözlük'te “Hafif kımıldamak, genellikle vücudun bir yerinde deri ile birlikte derinin hemen altındaki kaslar hafifçe oynamak" (2005: 1722) şseklinde tanımlanmış olup Derleme Sözlüğü’nde “Seğrimek, (sergimek, serimek, seyirmek, seyrimek) seğirmek" (1993:3566) “seyremek: az kıpırdamak (1993:3599) olarak yer almaktadır. Osmanlıca-Türkçe Ansiklopedik Lugat'ta ihtilâcnâmeler, "yüzün ve gözün seyirmesi hakkında yazılan bir çeşit mensur falnâme, fal kitabı" (Devellioğlu, 1999:419) olarak tanımlanmaktadır.

Falnâmeler olarak adlandırabileceğimiz türler özelde yıldıznâme, kıyafetnâme, ihtilâcnâme, tefe'ülnâme gibi adlarla isimlendirilmektedir. Ersoylu, ihtilacnâme ilminin Zülkarneyn veya Danyal'a nispet edilmesinin öteden beri sürdürülegelen bir inanç olmasına rağmen herhangi bir delile dayandırılmadığını söyler (Ersoylu,1985:27). Rivayete göre Danyal peygamberin bir kuyusu vardır. Hz. Adem hikmet sırlarını bu kuyuya saklamış ve o hikmeti oradan Hz. Danyal çıkarmıştır (Pala, 1998:99).

Ancak öyle veya böyle İslamî gelenek bakımından bir nevi fal olan ihtilâcnâmelere veya diğer fal türlerine sıcak bakılmadığı bilinmektedir. Dolayısıyla bu duruma dinî bir dayanak noktası teşkil edilmesi gerekmektedir. Nitekim "falnâmelerin ilkinin Hz. Ali’ye nispet edildiğine dair elimizde kaynak olmamakla beraber ehl-i beytten Cafer-i Sadık'a nispet edilen falnâmeler çoktur. Cafer-i Sadık'tan sonra en mühim falnâme Tefe'ülnâme-i Muhiddin Arabî adıyla Muhiddin Arabî’ye aittir” (Kara, 1979:155). Kur'an-1 Kerim'de her ne kadar “fal oklarıyla

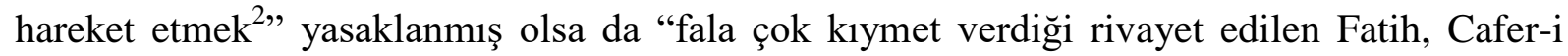
Sadık'ın falnâmesini düzenlettiği gibi Hamidiye'de Câm-1 Suhangûy adlı Farsça bir falnâme” (Kara,1979:155) hazırlatmıştır.

Bu hâliyle hem İslamiyetten önce hem de sonra ihtilacnâmeler rağbet görmüştür diyebiliriz. Vücut organlarının seğirmesi özellikle halk inanışında büyük yer tutmaktadır. Bunun tipik örneğini Dede Korkut Kitabı'nda görmek mümkündür. "Dirse Han Oğlu Boğaç Han Boyunu Beyan Eder" başlıklı destanda geçen "Çıksun benüm gözüm, a Dirse Han, yaman segrür” (Kaçalin, 2017:42) cümleleri önemli bir kaynaktır.

\section{Seğirnâmeler Hakkinda Umumî Değerlendirme:}

\footnotetext{
${ }^{2}$ Ey iman edenler! (Aklı örten) içki (ve benzeri şeyler), kumar, dikili taşlar ve fal okları ancak, şeytan işi birer pisliktir. Onlardan kaçının ki kurtuluşa eresiniz. Maide/ 90
} 
İhtilacnâmeler üzerinde günümüze değin pek çok çalışma yapıldığı bilinmektedir. Makalemizde bu çalışmaların belli başlılarını zikretmenin faydalı olacağı kanaatindeyiz.

Bilinen en eski seğirnâme nüshası Uygur harfleriyle yazılı olup Berlin Brendenburg Kütüphanesinde bulunmaktadır. Uygur harfli bu metin hakkında hem Reşit Rahmeti Arat hem de Peter Zieme çalışma yapmışlardır (Sertkaya, 2011:1534).

Seğirnâmeler hakkında ilk çalışma 1967 yılında Bosna-Hersek Gazi Hüsrev Bey Kütüphanesi'ndeki bir yazma üzerine Zajaczkowski’nin yaptığı çalışmadır. 1949'da Gagavuzların Tarihi, Dil ve Etnografyası adlı teziyle doktorasını veren Polonyalı Türkolog, Włodzimierz Zajączkowski, Polonya Türkolojisinde önemli bir yere sahiptir (Ersoylu, 1985:28).

Kemal Özergin, 1967 yılında Türk Folklor Araştırmaları Dergisi'nde iki farklı seğirnâme metni yayınlamıştır (Ersoylu, 1985:28), (Özergin, 1967).

Arif Özer, 1969 yılında "Türkçe İki Segirname Kitabı Üzerine" adlı makalesinde Zajaczkowski'nin yayınlamış olduğu iki seğirnâmeden birincisini tam metin ikincisini de bazı örneklerle yayınlamıştır (Özer, 1969).

Halil Ersoylu, 1985 yılında "Seğirnâme” başlıklı makalesinde Mevlana Müzesi yazmaları arasında bulunan bir yazmayı incelemiştir. Yazar, makalesinde metin için bir sözlük hazırlamış ve uzuvlar dizinine yer vermiştir (Ersoylu, 1985). Ersoylu, Türk Dili Araştırmaları Yıllığı Belleten'de yayınladığı "Seğirname II” başlıklı diğer makalesinde Topkapı Sarayı Müzesi Kütüphanesinde bulunan bir yazmadaki seğirnameyi değerlendirmiştir (Ersoylu, 1992).

Saadettin Özçelik, (1996) Millî Folklor Dergisi'ndeki "Bir İhtilac-name Üzerine” adlı makalesinde Diyarbakır İl Halk Kütüphanesi'nde kayıtlı bir mecmuanın içinde yer alan ihtilâcnâmeyi incelemiştir. Yazar, makalesinde incelenen metin için bir sözlük hazırlamış ve uzuvlar dizinine yer vermiştir.

Fatih Ramazan Süer, 2011 yılında Sivas Ziyabey Yazma Eserler Kütüphanesinde bulunan bir mecmuadaki seğirname metni üzerinde çalışmıştır (Süer, 2011).

Ayşe Gül Sertkaya (2011), "Bilinmeyen bir Seğir-nâme Yazması" başlıklı bildirisinde Türkiyat Araştırmaları Enstitüsü 24 numarada kayıtlı mecmuada bulunan seğirnâmeyi incelemiş ve seğirme dizini ile uzuv dizini oluşturmuştur. Yazar çalışmasında, yayımlanan seğirnâmeleri iki grupta değerlendirmiştir. Birinci gruptaki seğirnâmelerde sadece bir seğirme zikredilerek tabir edilmiş, ikinci grup seğirnâmeler ise karşılaştırmalı metin şeklinde düzenlenmiştir (Sertkaya, 2011:1533). 
Abdullah Mert (2016), Fransa Bibliotheque National (FBN) 242 numarada kayıtlı bir mecmuanın 66. varağında bulunan seğirnameyi incelemiştir. Yazar, metinde geçen bazı kelimelerin anlam karşılıklarını ve tarihî gelişimini vererek uzuv dizini ve seğirmeler dizini oluşturmuştur.

Seğirnâmeler hakkında kapsamlı çalışmalar Yusuf Ziya Sümbüllü’ye aittir. Sümbüllü, "Seğirnâme" adlı kitabında yazılı ve sözlü gelenekteki seğirme ilmini incelemiş, yurt içi ve yurt dışından toplam 58 yazmanın tespit edildiğini ifade etmiştir (Sümbüllü, 2014). Yazarın söz konusu kitaptan başka makaleleri de mevcuttur. Yazar, "Yeni Bir İhtilâcnâme Nüshası Üzerine Değerlendirme" (2016) başlıklı makalesinde Fransa Milli Kütüphanesi Türkçe Yazmaları Bölümü'nde Turc 21 numara ile kayıtlı yazmanın 82-94 yaprakları arasında yer alan ihtilâcnâme metni üzerinden değerlendirmelerde bulunmuştur. Sümbüllü'nün Mehmet Akif Gözütok’la hazırladıkları "Gaybî Bir İlim Şubesi Olarak İhtilâç-nâmeler ve Mevlânâ Sevâdî’nin Manzum İhtilâç-Nâmesi’'(2013) başlıklı makalede manzum bir seğirnâme incelenmiştir. İncelemeye konu olan seğirnâme metni İstanbul Araştırmaları Enstitüsü Şevket Rado Yazmaları, ŞR 525 numarada kayıtlı bir mecmuanın 260a-263b varakları arasında olan nüsha ile Bibliothèque nationale de France Kütüphanesi, Turc 21'de kayıtlı bir mecmuanın 23b-34a varakları arasında bulunan nüsha temelinde kurulmuştur (Sümbüllü, 2013:114). Yusuf Ziya Sümbüllü, "Seğir-Nâme ve Segirmek Manaları Üzerine Bir İnceleme" adlı makalesinde (2007) Erzurum Atatürk Üniversitesi Seyfettin Özege Kitaplı̆̆ında bulunan mensur bir metinden hareketle seğirmek kelimesini inceleyerek seğirnâmeler hakkında bilgi vermiştir. Bu makalede yazar metnin sonuna bir de sözlük hazırlamıştır.

Özkan Daşdemir, “İngiltere Kütüphanelerinde Kayıtlı Dört Seğirname Üzerine” (2016) adlı makalesinde Britanya Kütüphanesinde Arundel Or. 8 arşiv numarasıyla kayıtlı bir mecmuadaki seğirnâme örneğini; yine Britanya Kütüphanesindeki Harl. 5463 arşiv numarasıyla kayıtlı bir mecmuanın içindeki seğirnâmeyi; Britanya Kütüphanesinde Sloane 1081 arşiv numarasıyla kayıtlı 60 yapraktan oluşan bir mecmuadaki seğirnâmeyi ve Oxford Bodleian Kütüphanesi Türkçe Yazmalar Bölümünde MS Turk. e. 112 arşiv numarasıyla kayıtlı seğirnâmeyi incelemiştir (Daşdemir, 2016).

Tülay Çulha, "Karayca Bir İnceleme: Sekirme Yoraları" (2009) makalesinde Raddloff tarafından 1888 yılında yayınlanan Proben derlemelerinin VII. cildinde bulunan "Sekirme Yoraları" adlı metin üzerinde şekil bilgisi incelemesi yaparak gramatikal indeks hazırlamıştır (Çulha, 2009).

Mehmet Yastı, "Yeni Bir Seğir-nâme Yazması Üzerine" (2015) başlıklı makalesinde Fransa Bibliotheque National (FBN) 178 numarada kayıtlı mecmuanın 296-320. sayfaları arasında bulunan mensur seğirnâmeyi incelemiştir. Yazar, çalışmasında Ersoylu, Karaatlı ve Süer'in 
çalışmalarını karşılaştırmalı olarak vererek seğirmelere getirilen yorumları kıyaslamıştır (Yast1, 2015).

Şimdiye kadar seğirnâmeler/ ihtilacnâmeler hakkında yapılan ve ulaşabildiğimiz bu kaynaklar, kendi içerisinde edebî bir değer taşıdığı gibi özellikle imlâ hususiyetleri bakımından Türkçenin tarihî gelişimine ışık tutacak mahiyettedir.

\section{Seğirnâme Metni Ve Özellikleri:}

Çalışmamızın temelini oluşturan seğirnâme nüshası Leibzig Üniversitesi Kütüphanesi B. or. 080-10 numarada kayıtlı bulunan mensur bir metindir. Müstensihi Ahmed bin Muhammed elFünūnī olan metin tâlik yazı hattıyla istinsah edilmiştir. Metnin imlâ özellikleri bakımından hatasız olduğu söylenebilir. 3 sayfa hâlinde olan metnin birinci sayfası 23, ikinci sayfası 25 ve üçüncü sayfası 12 satırdan müteşekkildir. Yazma, bağımsız tek metin olarak kaleme alınmış olup kağıt boyu 21. 1x14. 7 cm, metin alanı 19. 8x14 cm'dir. Metinde toplam 138 seğirme yer almakta olup bu sayı hacimli sayılabilecek mahiyettedir. Metinde öncelikle sağ taraftaki uzuvlar ve seğirmeleri verilmiş, daha sonra sol taraftaki uzuvların seğirmeleri aktarılmıştır.

Seğirnâme nüshasının kelime kadrosu incelendiğinde şöyle bir görüntüyle karşılaşırız: Metnin imlâsındaki birkaç istisna dışında birlik dikkat çekicidir. Kelime tabanlarında imlâ farklılığı yoktur. Müstensih/ müellif imlâya hâkimdir denilebilir. Fakat metinde "şâd" kelimesi bazı yerlerde "şāz̄” imlâsıyla yazılmıştır: şād ola, şāz ola, şāżılık bula vb. Bu konuda Timurtaş, “ذ harfi ise, 15. yüzyıla kadar, د'dan önce uzun veya kısa sesli bulunduğu zaman د yerine kullanılmıştır" (Timurtaş, 1997:81) yorumunu yapmaktadır. İyilik kelimesinin yazımında da ikilik vardır. Kelime bir yerde "eyilik", başka bir yerde "eylük” imlâsıyla yazılmıştır. Benzer şekilde baldır kelimesinin yazımında da ikilik vardır. Kelime bir yerde "baldır" başka bir yerde "baldur" imlâsıyla kaleme alınmıştır. Benzer şekilde dudak kelimesi, metinde "duṭaġı" imlâsıyla yazılmışken hemen sonraki cümlede "țuṭggınuñ" imlâsıyla yazılmıştır.

Metinde uzuv isimlerinde Türkçe kelimeler kullanılmış, fakat metnin müellifi/ müstensihinin eğitim seviyesine göre Arapça ve Farsça kelimeler de tercih edilmiştir: nīkbaht, rūy, fütūḥ, ferah, küşāde, zemm vb.

İncelediğimiz nüshada bugün Türkiye Türkçesinde kullanımdan düşmüş olan "baylı̣̣/ zenginlik”, “söz keleci/ dedikodu”, “keleci/ söz, laf”, “öz/ kendisi” (Dilçin, 1983) kelimeleri de kullanılmıştır.

Metinde seğirmesi verilen uzuvlar şunlardır: başınuñ șaġyanı, depesi, depenüñ șag yanı, alnı,

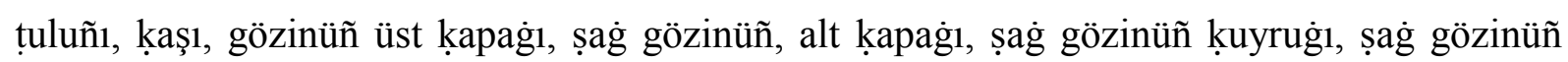
uc1, ögni, burnı, burnınuñ șag yanı, burnunuñ alt yanı, șag rūyı, șag̉ ḳulag̉ı, șag ḳulaġınuñ altı,

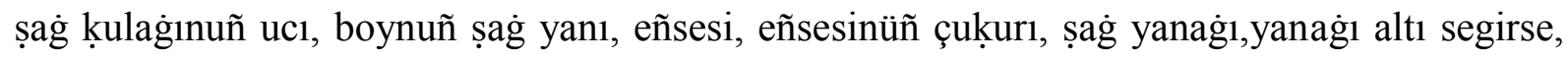




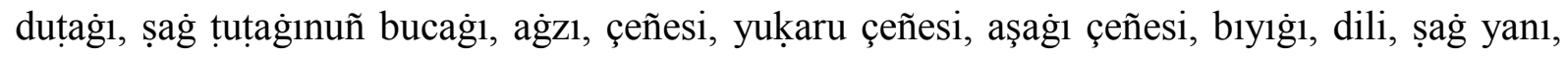
dilinüñ altı, dilüñ altı, ucı, boġazuñ șag் yanı, boġazı, șag் omuzı, șag் omuzı, ṣag் bazusı, șag்

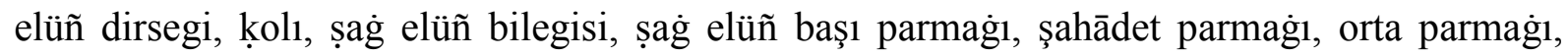

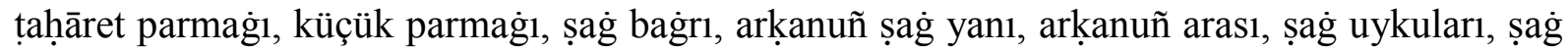
boġazı, emceginüñ çuḳurı, burnı, ḳarnı, ḳarnınuñ șaġ yanı, göbegi, göbeginüñ șag yanı, beli, ḳasuġ1, uyluġ1, uylug̉unuñ üsti, uylug̉unuñ altı, göti, götinüñ șag̉ yanı, götinüñ ortası, șag ḥayāsı, fercinüñ ucı, butı, dizi, dizinüñ șag yanı, baldırı, baldırınuñ üsti, baldırınuñ altı, incügi, șag̉ incügüñ üsti, incügüñ altı șag tobuğı, șag ayag்uñ incügi segirse, șag ayag̉uñ ortası, ṣag

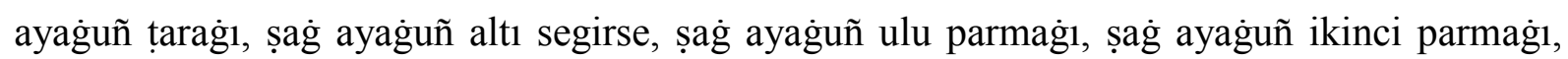

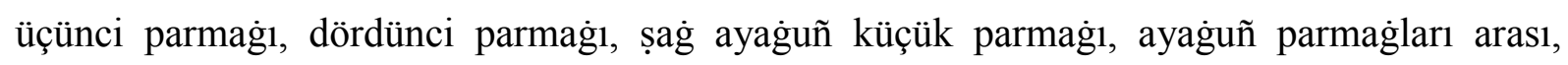
başınuñ ṣol yanı, alnınuñ șol yanı, șol țuluñı, șol ḳaşı, alnınuñ ṣol yanı, ṣol ḳaşınuñ ḳuyrugì, ṣol ḳaşı segirse, ṣol gözi, șol gözüñ yuḳaruki ḳapaġı, șol gözüñ yuḳarusı ḳapag̀ı, șol gözüñ ḳuyrugì1, șol gözüñ burnından yañası, șol gözüñ uc1, yañag்1 segirse, boġazınuñ șol yanı, ikisinüñ ṣol yanı, șol ḳulaġı, șol omuzı, ṣol bazusı, ṣol dirsegi, ṣol elüñ ayası, șol elinüñ arḳası, șol elüñ baş parmağı, elüñ şehādet parmağı, șol elüñ orta parmaġı, șol elüñ dördünci parmag̉ı, șol elüñ șerçe parmaġı, incügi segirse, șol uykuları, șol bağrı, ḳarnınuñ șol yanı, fercinüñ șol yanı, götinüñ șol yanı, șol budı, ṣol dizi, șol baldurı, șol ayagunñ incügi, ṣol

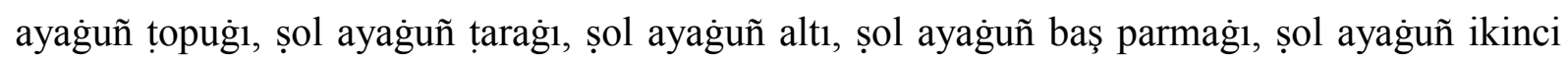

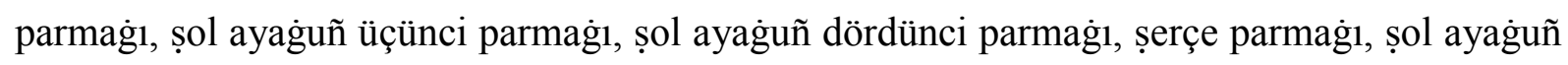
parmaḳlar arası.

\section{Metin:}

[1] (1) Bismillāhi'r-raḩmāni'r-rahīm. Eger başınuñ șag̉ yanı segirse rag̉bet ü firșat bula ululuk bula. Eger depesi segirse ululuk bula şād ola. (2) Eger bir kezden başı segirse cizzet ü firṣat bula. Eger depenüñ șag̉ yanı segirse şād ola sevine. Eger alnı segirse azıcık melūl ola șoñra (3) şād ola. Eger alnınuñ șag̉ yanı segirse sevine şād ola. Eger alnınuñ arası segirse șavāş ide. Eger țuluñı segirse göñli (4) dilegine irişe. Eger ḳaşı segirse ḳavmiyle görişe. Eger gözinüñ üst ḳapaġı segirse borcı ödene. Eger șaġ gözinüñ alt (5) ḳapaġı segirse şāz̄ılı̣̣ bula sevine. Eger șag gözinüñ ḳuyruġı segirse ādem seve şāz ola sevine. Eger șag gözinüñ ucı (6) segirse şāżıluḳ bula sevine. Eger ögni segirse nīkbaht ola sevine. Eger burnı segirse eline bir nesne gire. Eger burnınuñ șaġ yanı (7) segirse şāẑılı̣̣ bula sevine. Eger burnunuñ alt yanı segirse ḥaber işide sevine. Eger șag̉ rūyı segirse ḳatı sevine şād ola. Eger șag (8) ḳulag̉ı segirse ḥōş ḥaber işide māl nímet eline gire. Eger șag̉ ḳulaġınuñ altı segirse fütūḥ eline gire. Eger șag ḳulag̉ınuñ ucı segirse (9) șavāş eyleye. Eger boynuñ șag̉ yanı segirse mālı arta bereketi ziyāde ola. Eger eñsesi segirse șavāş eyleye. Eñsesinüñ çuḳurı segirse yalan (10) söyleye. Eger șag̀ yanaġı segirse şāz ola sevine. Eger yanag̉ı altı segirse azıcıḳ guușṣalu ola. Duțaġı segirse yavuz 
keleci eyleye. Șag் (11) țuṭaġnuñ bucağı segirse o nímet-i țūl ola. Eger aġzı segirse māl u nímet çoḳ ola. Eger çeñesi segirse söz gele ḥaber eyleye. Eger (12) yuḳaru çeñesi segirse guș̣̦alana. Eger aşaġı çeñesi segirse gāâyib gele. Eger bıyıg்ı segirse gayg̉ulı ola. Eger dili segirse ululuḳ bula (13) sevine. Eger șag yanı segirse şād ola sevine. Eger dilinüñ altı segirse azıcık gușṣalu ola. Eger dilüñ altı segirse göñli açıla. Ucı (14) segirse ululuḳ bula sevine. Eger boġazuñ șag் yanı segirse ḳayg்udan ḳurtula. Eger boġazı segirse şāžılıḳ bula sevine. Eger șag omuzı (15) segirse baylı̣ u ḥurmet bula. Eger șag omuzı segirse göñli feraḥ bula açıla. Eger ṣag̉ bazusı segirse ol kimesne sevine. Eger șag̉ (16) elüñ dirsegi segirse şāa ola. Eger ḳolı segirse bayluḳ bula sevine. Eger șaġ elüñ bilegisi segirse nesne eline gire sevine. (17) Eger ṣag elüñ başı parmag̀ı segirse gușṣadan emīn ola. Eger şahādet parmag̉ı segirse yavuz iş ide tevbe eyleye. Eger orta parmag் (18) segirse tevbesi ḳabūl ola. Eger tahāāet parmağı segirse sefer eyleye. Eger küçük parmaġı segirse şāžılıḳ bula. Eger șaġ baġrın segirse göñli (19) küşāde ola. Eger arḳanuñ șag̉ yanı segirse göñli şāz ola ve özi feraḥ ola. Eger arḳanuñ arası segirse 'azizlik (20) bula. Eger șag̉ uykuları segirse ḩayrlulardan ola. Eger șag̉ boġazı segirse şāẑllı̣ bula. Eger emceginüñ çuḳurı segirse ya vaḳitlenmiş (21) nesnesin bula. Eger burnı segirse azıcık guș̣̦alu ola. Eger ḳarnı segirse sevine feraḥ bula. Eger ḳarnınuñ șag் yanı segirse rahat ola. (22) Eger göbegi segirse dōstunı göre sevine. Eger göbeginüñ șag yanı segirse şāẑılıḳ bula. Eger beli segirse vādi üzerine irişe. (23) Eger ḳasuġı segirse şāz̄ ola. Eger uylugì segirse ol kişiye ululardan eyilük irişe. Eger uylug̉unuñ üsti segirse [2] (1) vaḳti ḩōş ola. Eger uylugiunuñ altı segirse yavuzluḳdan emīn ola. Eger göti segirse rūz̄ī irişe şād ola. Eger (2) götinüñ șag̉ yanı segirse göñli küşāde ola. Eger götinüñ ortası segirse vațan degişdüre. Eger șag̉ ḥayāsı segirse (3) cizzet bula. Eger fercinüñ ucı segirse evlene. Eger butı segirse ḳalbi küşāde ola. Eger dizi segirse şāžllı̣̣ bula sevine. Eger dizinüñ (4) șag̉ yanı segirse ferah eline gire. Baldırı segirse gāâyib kişi gele. Eger baldırınuñ üsti segirse şāžllı̣ bula. Eger baldırınuñ (5) altı segirse azıcık ḳayg̉u ola. Eger incügi segirse yalan söz söyleye. Eger șag incügüñ üsti segirse yalan söz işide. Eger (6) incügüñ altı segirse göñli açıla. Eger șag tobugì segirse rāḥat

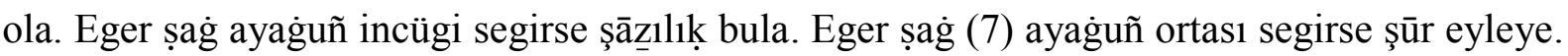
Eger șag̉ ayag்uñ țarag்ı segirse azıcık ḳayg்ulu ola. Eger șag் ayag்uñ altı segirse sefere gide. (8)

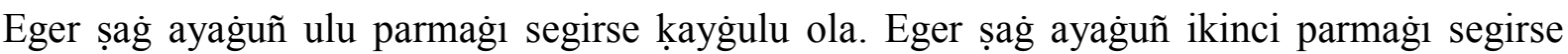
melūl ola. Eger üçünci parmağı segirse ululuḳ bula. (9) Dördünci parmag்ı segirse gāayibden araması gele. Eger șag ayag̉uñ küçük parmağ1 segirse murādı ḥāṣıl ola. Eger ayaġuñ parmaġları arası (10) segirse og̉lı tọga. Eger iẓlāc-ı itrāḳ rāst. Lāya'lemu'l-ġaybe illā hū. Ve māhüve fí'l-berri ve'l-baḥri ve mātesḳuṭu minvaraḳatin illā ya'lemuhā (11) ve lāḥabbetin fịzulumāti'l-arżı ve lāraṭbin ve lāyābisin illā fīkitābin mübīn. Lāya'lemu'l-g̉aybe 'allame'lguyū $b^{3}$ hazāa bābu hallācnāme 1ṭāḳun ve ḥubsi.

${ }^{3}$ Gaybı O’ndan başkası bilmez. "Karada ve denizde olanı da bilir. Hiçbir yaprak düşmez ki onu bilmesin. Yerin 
Bismillāhi'r-raḩmāni'r-rahīm (12) Eger başınuñ șol yanı segirse ol kişi āyet-i ululuḳ bula. Eger alnınuñ șol yanı segirse (13) ol kişi 'azīz ola. Eger șol țuluñı segirse ol kişi ḥōş haber işide. Eger șol ḳaşı segirse șavāş ola. Eger alnınuñ (14) șol yanı segirse şāz̨ ola. Eger ṣol ḳaşınuñ ḳuyruġı segirse melūl ola. Eger șol ḳaşı segirse ḩayr ḩaber işide. Eger șol (15) gözi segirse gāyibden kimesne gele hayırla. Eger ṣol gözüñ yuḳaruki ḳapaġı segirse şāżllı̣ bula. Eger șol gözüñ yuḳarusı (16) ḳapağı segirse ḳayg̉ulu ola. Eger ṣol gözüñ ḳuyruġı segirse şāżılıḳ bula sevine. Eger șol gözüñ burnından yañası segirse (17) zemmüñ işitmek ola. Eger șol gözüñ ucı segirse dilegine yitişe. Eger yañaġı segirse 'ākıbeti hayr ola sevine. Eger boġazınuñ șol (18) yanı segirse ol kişi yalan söyleye. İkisinüñ șol yanı segirse ḳalbi ferah

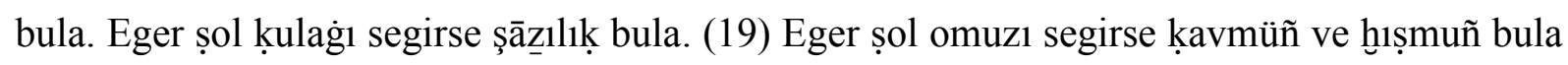
şāz̄ılığla. Eger șol bazusı segirse ferạ̣ bula. Eger ṣol dirsegi (20) segirse ḳayg̉ulu ola. Eger ṣol elüñ ayası segirse ḥelālden fütūḥ eline gire. Eger șol elinüñ arḳası segirse azıcı̣ melūl (21) ola. Eger șol elüñ baş parmaġı segirse ġuș̣a vāḳı cola. Eger elüñ şehādet parmaġı segirse ṣavāş eyleye. Eger ṣol (22) elüñ orta parmag̀ı segirse ol kişi ḥōş ola. Eger ṣol elüñ dördünci parmag̉ı segirse çoḳ sevine. Eger șol elüñ (23) șerçe parmaġı segirse şeksüz evine ḳonak gele. Eger incügi segirse vaḳti ḥōş ola. Eger șol uykuları segirse yavuz (24) belālardan emīn ola. Eger șol bağrı segirse ululuḳ bula sevine. Eger ḳarnınuñ șol yanı segirse murādı ḥāṣıl ola. (25) Eger fercinüñ șol yanı segirse murādına irişe. Eger götinüñ ṣol yanı segirse gāàibden nesne eline gire. [3] (1) Eger șol budı segirse sefer eyleye mübārek ola. Eger ṣol dizi segirse bir kimseyle söz keleci eyleye. Eger șol baldurı segirse ululuk (2) bula. Eger șol ayaġuñ incügi segirse düşman ola. Eger șol ayaġuñ țopuğı segirse bahtlluḳ yetişe adına. Eger șol ayaġuñ (3)

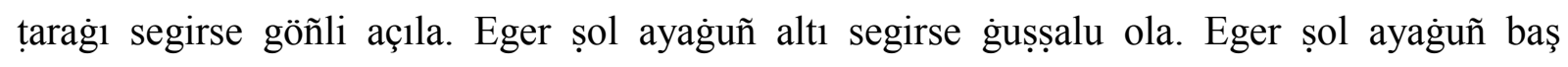
parmag்ı segirse șavāş eyleye. Eger (4) șol ayag̉uñ ikinci parmag̉ı segirse bir iş işleye kim andan ötüri eyilik göre. Eger șol ayag̉uñ üçünci parmag்ı segirse (5) ġuṣṣalana. Eger ṣol ayaġuñ dördünci parmaġı segirse eylükler göre. Eger șerçe parmaġı segirse çoḳ ‘ibādet ide. Eger șol (6) ayag̉uñ parmaḳlar arası segirse ululuk bula sevine. İhlā̄c-1 ețāaf-ı ceb. Lā ya'lemu'l-ġaybe illā hüve ve ya'lemumāfî̀'l-berri (7) ve'l-baḥri ve mātesḳuṭu minvaraḳatin illā ya'lemuhā ve lāḥabbetin fî̀zulumāti'l-arżı ve lāraṭbin ve lāyābisin illā fỉkitābin mübīn ${ }^{4}$. Tamam. (8) Temmetü'l-kitāb bi‘avnillāhi'l-meliki'l-vehhāb5 (9) Terzuḳu menteşā' big̉ayrı ḥisābin ${ }^{6}$ (10) Aḥmed bin Muḥammed el-Fünūnī (11) Kātiben reis (12) Kitābu’l-ḳalem

\footnotetext{
karanlıklarında da hiçbir tane, hiçbir yaş, hiçbir kuru şey yoktur ki apaçık bir kitapta (Allah'ın bilgisi dahilinde, Levh-i Mahfuz'da) olmasın. ” En’am/ 59 Gaybı O’ndan başkası bilmez.

${ }^{4}$ Gaybı O'ndan başkası bilmez. "Onları ancak O bilir. Karada ve denizde olanı da bilir. Hiçbir yaprak düşmez ki onu bilmesin. Yerin karanlıklarında da hiçbir tane, hiçbir yaş, hiçbir kuru şey yoktur ki apaçık bir kitapta (Allah'ın bilgisi dahilinde, Levh-i Mahfuz'da) olmasın." En'am/ 59 Gaybı O'ndan başkası bilmez.

5 Allah'ın yardımıyla kitap tamamlanmıştır.

6 "Dilediğine de hesapsız rızık verirsin. " Âl-i İmrân/ 27
} 


\section{Sonuç}

Edebî metinlerin en mühim vasfı içinden çıktığı cemiyetin aynası olmasıdır. Bu ayna her türlü düşünüş, yaşayış, idrak ve anlayışı yansıtır. Edebiyat araştırmacısı ise yapacağı her tür incelemeyle bu aynayı biraz daha cilalayan kişidir.

İnsan bedeninin herhangi bir organının seğirmesine dayanılarak yapılan yorum işine ilm-i ihtilâc adı verilmektedir. Bir fal çeşidi olan vücut organlarının kımıldaması üzerine yapılan yorumlar neticesinde manzum veya mensur pek çok eser kaleme alınmıştır ki bunlar edebiyat tarihimizde seğirnâme veya ihtilâcnâme adıla anılır.

Bu çalışmanın konusunu teşkil eden seğirnâme nüshası Leibzig Üniversitesi Kütüphanesi B. or. 080-10 numarada kayıtlı bulunan mensur bir metindir. 138 seğirmenin yer aldığ metinde uzuv isimlerinde Türkçe kelimeler kullanılmış olmakla birlikte Arapça ve Farsça kelimelere de yer verilmiştir: nīkbaḩt, rūy, fütūḥ, ferạ̣, küşāde, zemm vb. İncelediğimiz metin, dil özelliklerine göre, 16. -17. yüzyıllara ait olabilir.

Yapılan çalışmalar incelendiğinde seğirnâme metinlerinin çoğunlukla mensur metinler olduğu, ancak manzum seğirnâmelerin de bulunduğu görülmüştür. İster manzum ister mensur olsun seğirnâme metinleri müstakil olarak kaleme alındığı gibi herhangi bir mecmuanın içerisinde bir bölüm olarak da kaleme alınmıştır.

Seğirnâme metinleri hem dil özellikleri hem de kültür tarihindeki yerleri bakımından önem arz etmektedir. Bundan sonraki süreçte yeni nüshaların tespitiyle Türk edebiyatında ilginç bir tür olan seğirnâmeler hakkında yeni çalışmalar yapılacaktır. Bu vesileyle, edebiyatın ve dilin tarihî serüvenini, kaynaklarını, kültürel arka planını, geçirdiği evreleri ilmî olarak tespit etmek ancak edebî eserlerin çözümüyle mümkün diyebiliriz. Dolayısıyla eski edebî metinlerin akademik anlamda aktarılması da son derece önemlidir.

\section{Kaynakça / References}

Çulha, Tülay (2009). "Karayca Bir İnceleme: Sekirme Yoraları”. Dil Araştırmaları Dergisi, Bahar, S. 4, S. 37-55.

Daşdemir, Özkan (2016). "İngiltere Kütüphanelerinde Kayıtlı Dört Seğirname Üzerine” Dede Korkut Uluslararası Türk Dili Ve Edebiyatı Araştırmaları Dergisi C. 5, S. 11, S. 19-46.

Devellioğlu, Ferit (2003). Osmanlıca-Türkçe Ansiklopedik Lûgat, Ankara: Aydın Kitabevi.

Dilçin, Cem (1983). Yeni Tarama Sözlüğü. Ankara: Türk Dil Kurumu Yayınları.

Ersoylu, Halil (1985). "Seğir-Name”. Türk Dili Araştırmaları Yıllığı (Belleten),Ankara, S. 27-48.

Ersoylu, Halil (1992). “Seğir-Name II”. Türk Dili Araştırmaları Yıllığı (Belleten), Ankara, S. 99-145. 
Kaçalin, Mustafa S. (2017). Oğuzların Diliyle Dedem Korkudun Kitabı. Ankara: Türk Dil Kurumu Yayınları.

Kara, İsmail (1979). "Falnâme". Türk Dili Ve Edebiyatı Ansiklopedisi C. 3. İstanbul: Dergah Yayınları.

Kartallığlu, Yavuz (2011). Klasik Osmanlı Türkçesinde Eklerin Ses Düzeni (16, 17, Ve 18. Yüzyıllar). Ankara: Türk Dil Kurumu Yayınları.

Mert, Abdullah (2016). "Bir Seğir-Name Nüshası". Türük Uluslararası Dil, Edebiyat Ve Halkbilimi Araştırmaları Dergisi. Y11:4, S. 7,S. 220-232.

Özçelik, Saadettin (1996). "Bir İhtilac-Name Üzerine”. Millî Folklor Türk Dünyası Folklor Dergisi, S. 31-32-Güz, S. 98-111.

Özer, Arif (1969). “Türkçe İki Segirname Kitabı Üzerine”. Türk Kültürü, Y11 7, S. 77. S. 48-52.

Özergin, Muammer Kemal (1967). "Eski Bir Seyirme-Nâme”, Türk Folklor Araştırmaları, 10, S. 211, Şubat 1967.

Pala, İskender (1998). Ansiklopedik Divân Şiiri Sözlüğü. İstanbul: Ötüken Yayınları.

Sertkaya, Ayşe Gül (2011). "Bilinmeyen Bir Seğir-Nâme Yazması”, 38. Icanas. 10-15. 09. 2007. Ankara-Türkiye. Bildiriler: Dil Bilimi, Dil Bilgisi Ve Dil Eğitimi. Ankara, 2011, S. 1533-1560.

Süer, Fatih Ramazan (2011). "Bir Seğirname Örneği”. Turkish Studies - International Periodical For The Languages, Literature And History Of Turkish Or Turkic, Volume 6/4 Fall 2011, P. 287-304.

Sümbüllü, Yusuf Ziya (2007). "Seğir-Nâme Ve Segirmek Manaları Üzerine Bir İnceleme”. Atatürk Üniversitesi Türkiyat Araştırmaları Enstitüsü Dergisi, S. 32, S. 53-69.

Sümbüllü, Yusuf Ziya \& Gözitok, Mehmet Akif (2013). "Gaybî Bir İlim Şubesi Olarak İhtilâçNâmeler Ve Mevlânâsevâdî'nin Manzum İhtilâç-Nâmesi”. Dede Korkut Türk Dili Ve Edebiyatı Araştırmaları Dergisi, 3(6), 105-131.

Sümbüllü, Yusuf Ziya (2016). "Yeni Bir İhtilâcnâme Nüshası Üzerine Değerlendirme”. Türk Ve İslam Dünyası Sosyal Araştırmalar Dergisi. Y11: 3, S. 6, S. 174-196.

Timurtaş, Faruk Kadri (1997). Osmanlı Türkçesine Giriş. İstanbul: Alfa Yayıncılık.

Türk Dil Kurumu (2005). Türkçe Sözlük, 10. Bask1, Ankara: Türk Dil Kurumu Yayınlar1.

Türkiye Halk Ağzından, Derleme Sözlüğü (1993). C. 10, Ankara: Tdk Yayınları.

Yasti, Mehmet (2015). "Yeni Bir Seğir-Nâme Yazması Üzerine”. Türkiyat Mecmuası, C. 25, Bahar, 275-314.

\section{Other Sources}

http://kuran. diyanet. gov. tr/mushaf/kuran-meal-2/maide-suresi-5/ayet-90/diyanet-isleribaskanligi-meali-1 Erişim Tarihi: 02/05/2017

http://kuran. diyanet. gov. tr/mushaf/kuran-meal-2/enam-suresi-6/ayet-59/diyanet-isleribaskanligi-meali-1 Erişim Tarihi: 08/05/2017 


\section{Appendix / Ekler}

\section{Tipkıbasım:}

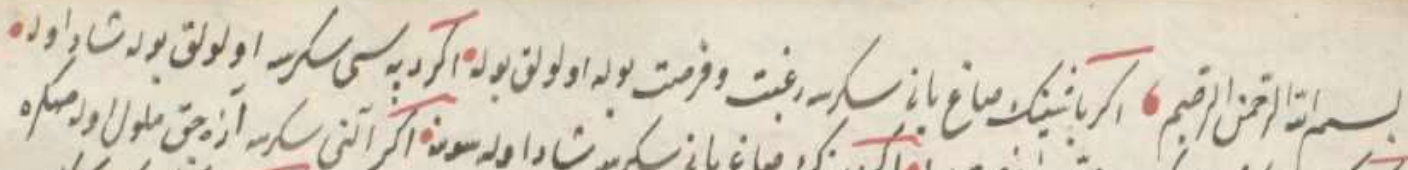

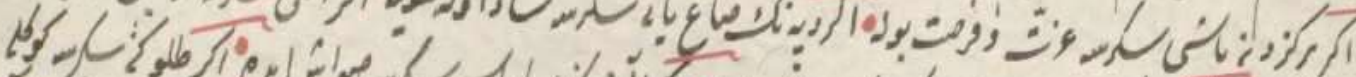

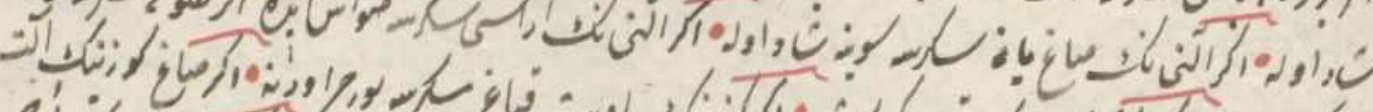
9, و il

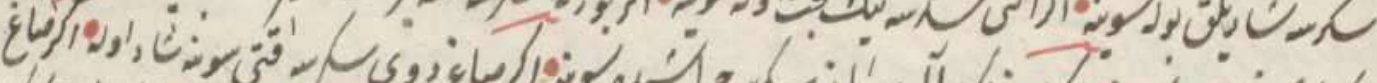

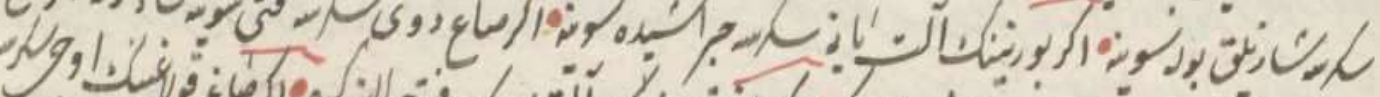
o -

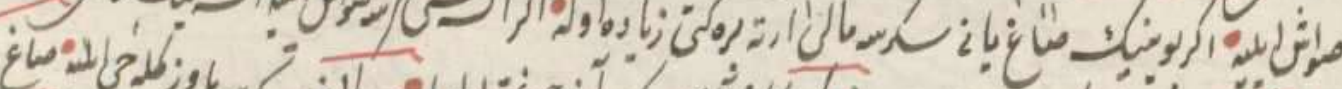
Fiqbir robا سون

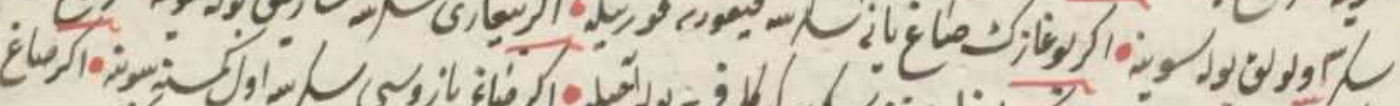

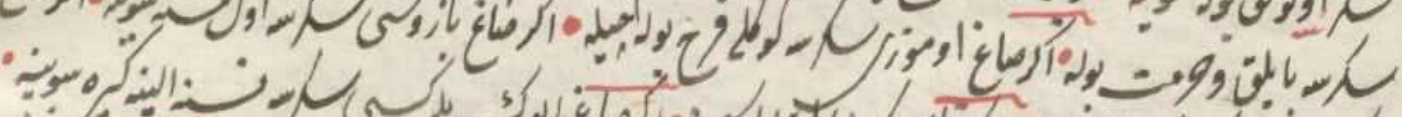

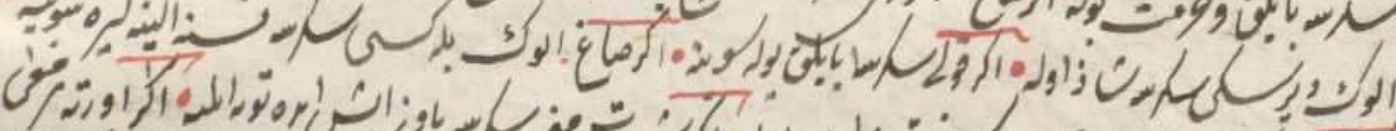

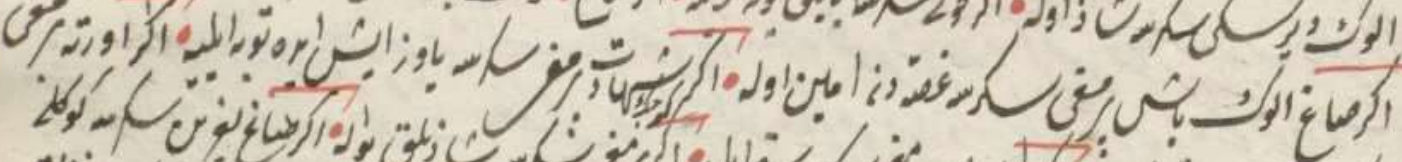
تأن

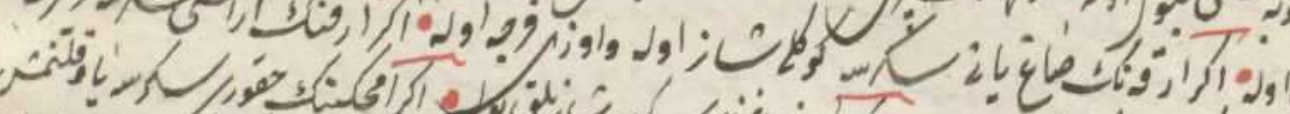
- a

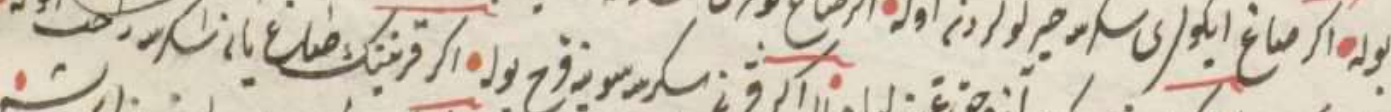
年, i,

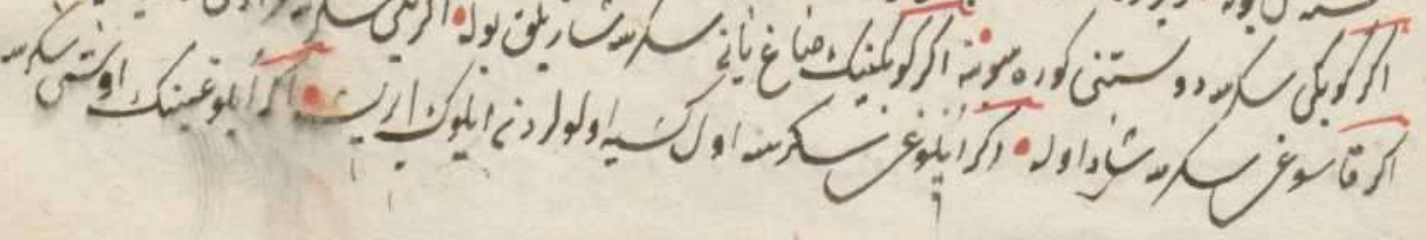




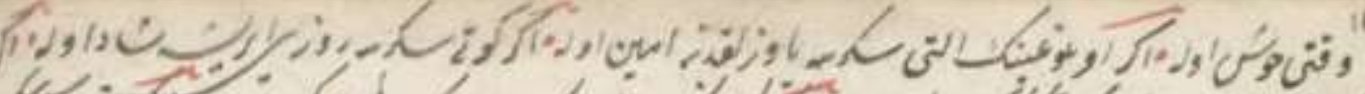

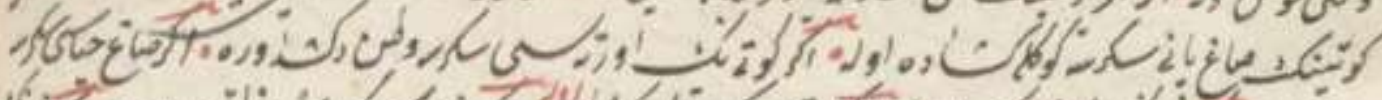
و ت

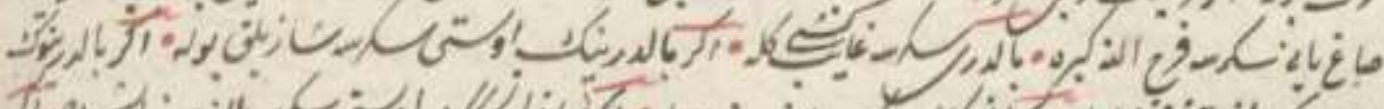

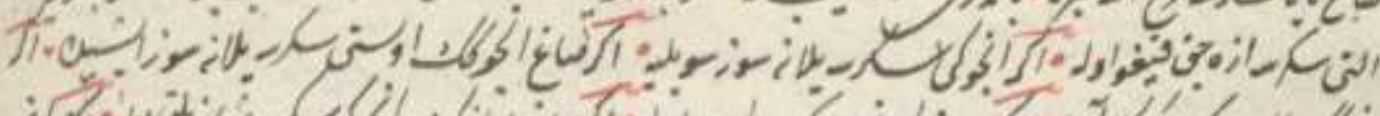

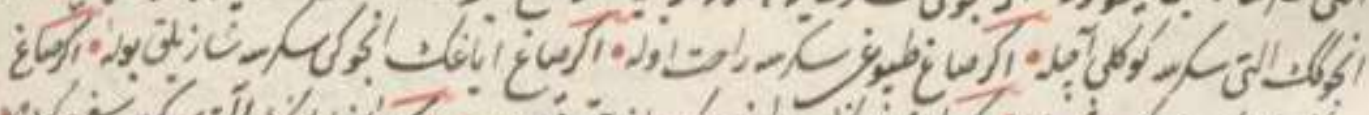
* o i (1)

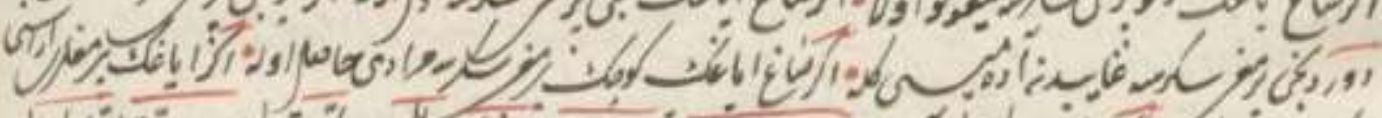

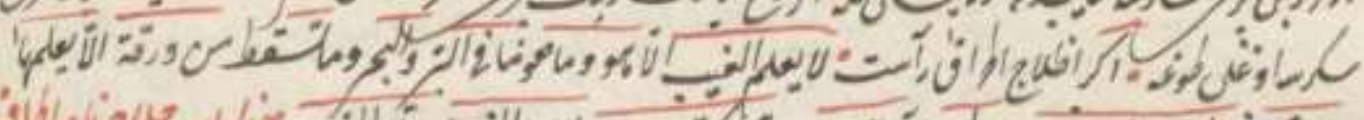

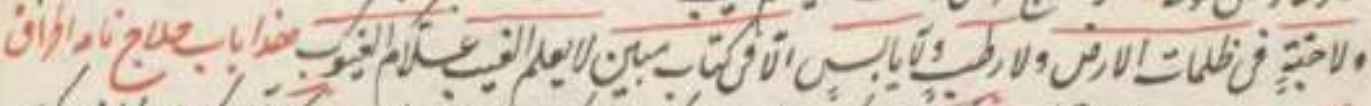
L

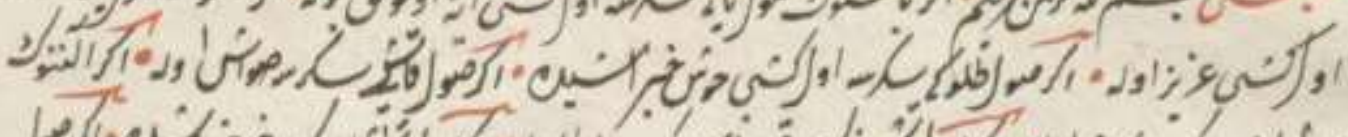

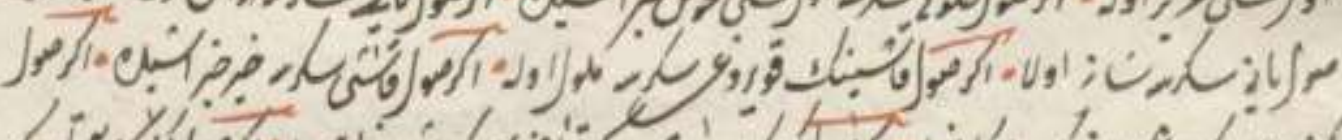
oا U J Q

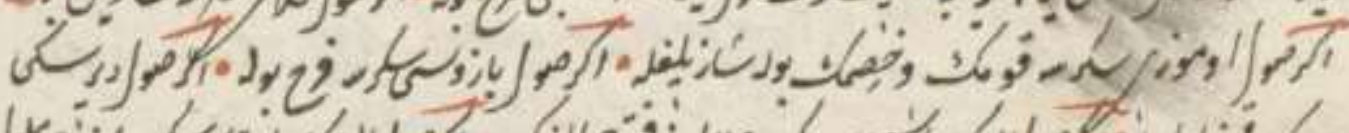

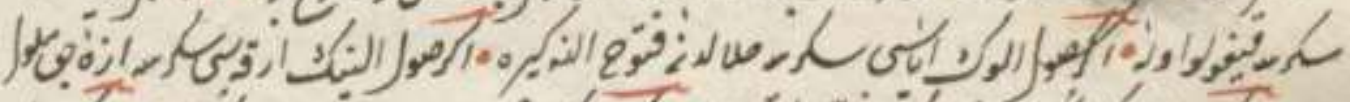

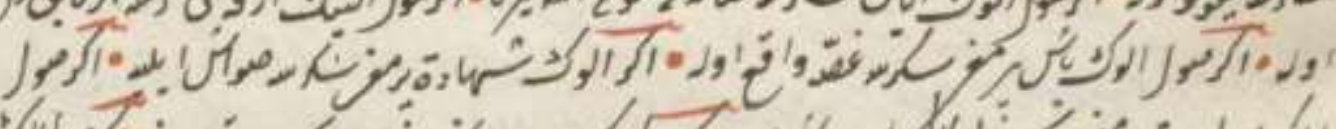

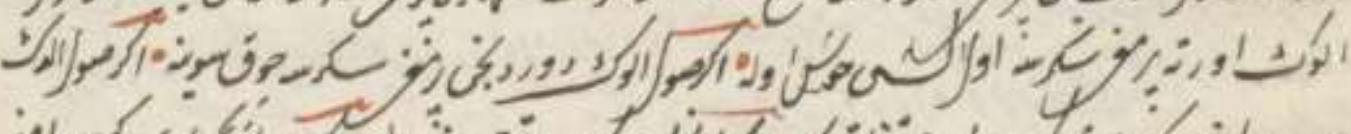

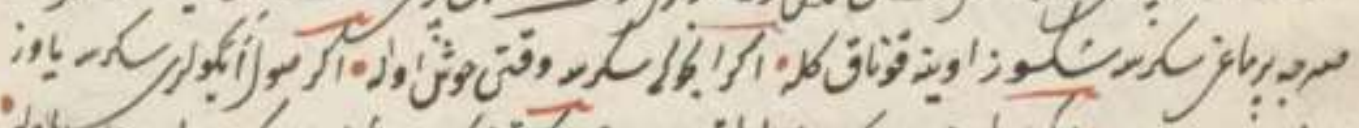

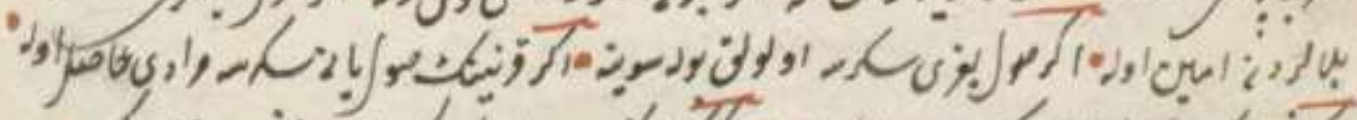

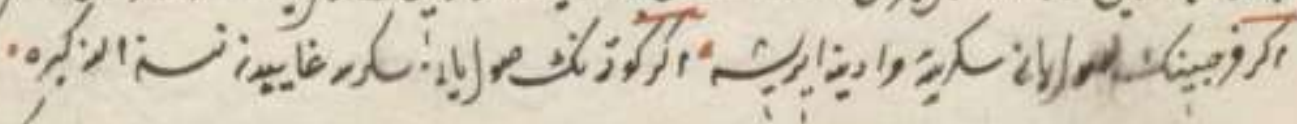
$\int 1$ 


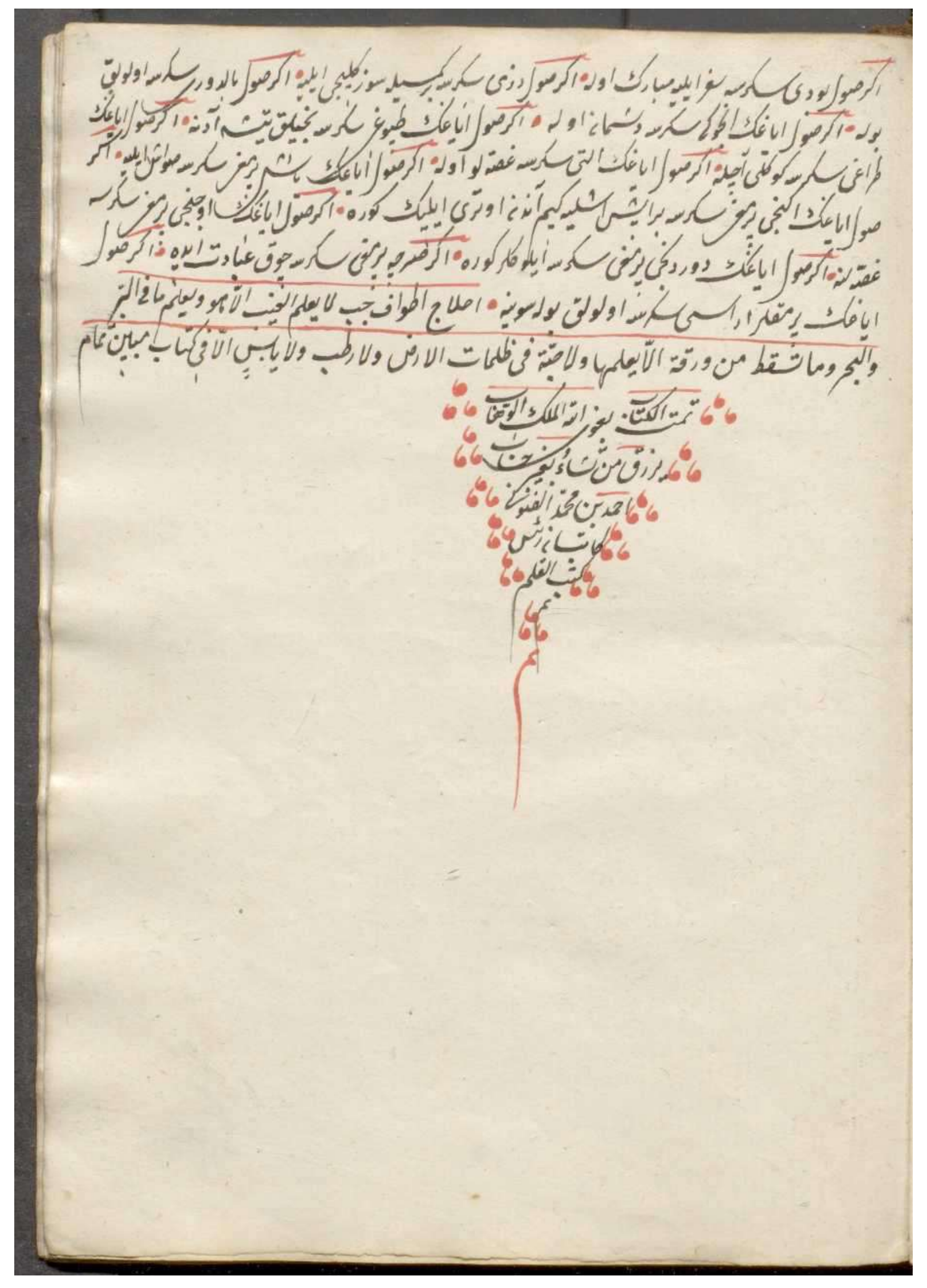

